\title{
Pre- and Postsynaptic Activation of GABA Receptors Modulates Principal Cell Excitation in the Piriform Cortex
}

\author{
Leah B. Gerrard ${ }^{\dagger \neq}$, Malinda L. S. Tantirigama ${ }^{\dagger}$ and John M. Bekkers* \\ Eccles Institute of Neuroscience, John Curtin School of Medical Research, The Australian National University, \\ Canberra, ACT, Australia
}

OPEN ACCESS

Edited by:

Qi Yuan,

Memorial University of Newfoundland, Canada

Reviewed by: Nathan Schoppa University of Colorado Denver School of Medicine, United States Hiroyuki Kato,

University of North Carolina, Chapel Hill, United States

${ }^{*}$ Correspondence: John M. Bekkers john.bekkers@anu.edu.au

† Joint first authors.

¥Present address: Leah B. Gerrard, Faculty of Engineering and Information Technology, University of Technology Sydney, Ultimo, NSW, Australia

Received: 01 December 2017 Accepted: 18 January 2018 Published: 05 February 2018

Citation: Gerrard LB, Tantirigama MLS and Bekkers JM (2018) Pre- and Postsynaptic Activation of $G A B A_{B}$ Receptors Modulates Principal Cell

Excitation in the Piriform Cortex.

Front. Cell. Neurosci. 12:28.

doi: $10.3389 /$ fncel.2018.00028
The piriform cortex $(\mathrm{PC})$, like other cortical regions, normally operates in a state of dynamic equilibrium between excitation and inhibition. Here we examined the roles played by pre- and postsynaptic $\mathrm{GABA}_{B}$ receptors in maintaining this equilibrium in the PC. Using whole-cell recordings in brain slices from the anterior PC of mice, we found that synaptic activation of postsynaptic $G_{A B A}$ receptors hyperpolarized the two major classes of layer 2 principal neurons and reduced the intrinsic electrical excitability of these neurons. Presynaptic $G_{A B A}$ receptors are expressed on the terminals of associational (intracortical) glutamatergic axons in the PC. Heterosynaptic activation of these receptors reduced excitatory associational inputs onto principal cells. Presynaptic $\mathrm{GABA}_{\mathrm{B}}$ receptors are also expressed on the axons of GABAergic interneurons in the $\mathrm{PC}$, and blockade of these autoreceptors enhanced inhibitory inputs onto principal cells. Hence, presynaptic $\mathrm{GABA}_{\mathrm{B}}$ autoreceptors produce disinhibition of principal cells. To study the functional consequences of $\mathrm{GABA}_{\mathrm{B}}$ activation in vivo, we used 2-photon calcium imaging to simultaneously monitor the activity of $\sim 200$ layer 2 neurons. Superfusion of the $\mathrm{GABA}_{B}$ agonist baclofen reduced spontaneous random firing but also promoted synchronous epileptiform activity. These findings suggest that, while $\mathrm{GABA}_{B}$ activation can dampen excitability by engaging pre- and postsynaptic $\mathrm{GABA}_{B}$ heteroreceptors on glutamatergic neurons, it can also promote excitability by disinhibiting principal cells by activating presynaptic $G_{A B A}$ autoreceptors on interneurons. Thus, depending on the dynamic balance of hetero- and autoinhibition, $\mathrm{GABA}_{\mathrm{B}}$ receptors can function as variable modulators of circuit excitability in the PC.

Keywords: 2-photon, epilepsy, GABA ${ }_{B}$, modulation, piriform cortex

\section{INTRODUCTION}

The piriform cortex (PC) is a three-layered paleocortex that is thought to generate holistic representations of odors, using information about the chemical components of inhaled odors that is provided by the upstream olfactory bulb (OB; Gottfried, 2010; Wilson and Sullivan, 2011). Layer 2 of the PC contains high densities of two distinct populations of glutamatergic principal cells: semilunar (SL) cells in layer $2 \mathrm{a}$ that mostly receive afferent inputs from the OB; and superficial pyramidal (SP) cells in layer $2 \mathrm{~b}$ that receive OB input and feedforward excitation 
from SL cells, as well as associational (intracortical) inputs from other SP cells (Neville and Haberly, 2004; Bekkers and Suzuki, 2013). SL and SP cells also receive feedforward inhibition from neurogliaform and horizontal cells, which are GABAergic interneurons that occupy the superficial layer 1a of the PC. Feedback inhibition is provided by a variety of interneurons in deeper layers, including bitufted, fast-spiking, chandelier, regular-spiking and deep neurogliaform cells (Suzuki and Bekkers, 2010a,b, 2012). These inhibitory circuits in the PC are of particular interest because of their modulatory roles in odor processing (Poo and Isaacson, 2011; Large et al., 2016).

$\mathrm{GABA}_{\mathrm{B}}$ receptors are G-protein-coupled receptors of GABA which provide slow inhibitory control of synaptic transmission and neuronal excitability (Bettler et al., 2004). GABA G $^{-}$mediated neurotransmission is important because it is critical for normal neural processing, as well as being linked to disorders like epilepsy, and because of the therapeutic use of the $G_{A B A}$ receptor agonist baclofen in humans (Schuler et al., 2001; Schuele et al., 2005). $\mathrm{GABA}_{\mathrm{B}}$ receptors are expressed postsynaptically in somatodendritic compartments, where their activation opens inwardly rectifying $\mathrm{K}^{+}$channels (Newberry and Nicoll, 1985; Andrade et al., 1986). $\mathrm{GABA}_{\mathrm{B}}$ receptors are also located presynaptically in the axon terminals of both excitatory neurons (heteroreceptors) and inhibitory interneurons (autoreceptors), where their activation inhibits $\mathrm{Ca}^{2+}$ influx via $\mathrm{N}$ or P/Q-type $\mathrm{Ca}^{2+}$ channels, leading to decreased neurotransmitter release (Harrison, 1990; Scholz and Miller, 1991; Bettler et al., 2004).

In the $\mathrm{PC}$, it is known that postsynaptic $\mathrm{GABA}_{\mathrm{B}}$ receptors give rise to a slow inhibitory postsynaptic potential in SP cells (Tseng and Haberly, 1988), but it is not known if a similar $\mathrm{GABA}_{\mathrm{B}^{-}}$ mediated response is present in SL cells. On the presynaptic side, $\mathrm{GABA}_{\mathrm{B}}$ heteroreceptors are known to be present on associational excitatory synapses on both SL and SP cells (Tang and Hasselmo, 1994; Franks and Isaacson, 2005; Suzuki and Bekkers, 2011), but the physiological conditions under which they might be activated are still unclear. $\mathrm{GABA}_{\mathrm{B}}$ autoreceptors have also been reported on inhibitory presynaptic terminals in the PC (Kapur et al., 1997) but, again, it is unknown whether both SL and SP cells are the targets of these terminals and under what conditions these autoreceptors are active. Finally, questions remain about the significance of $\mathrm{GABA}_{\mathrm{B}}$ receptor activation for odor processing in vivo (Poo and Isaacson, 2011; Riffell et al., 2014).

Here, we addressed these issues using whole-cell patch clamp recordings in brain slices and two-photon calcium imaging in vivo. We found that activation of postsynaptic $\mathrm{GABA}_{\mathrm{B}}$ receptors hyperpolarize both SL and SP cells, reducing their excitability. We also found that $G_{A B A}$ receptors located on glutamatergic or GABAergic terminals function as heteroreceptors or autoreceptors, respectively, to reduce EPSC or IPSC amplitudes in principal cells, with some differences between SL and SP cells. Finally, we found that $\mathrm{GABA}_{B}$ activation has dual effects on the PC circuit in vivo, on the one hand suppressing spontaneous activity in principal cells, and on the other hand promoting intermittent epileptiform activity in the same cells. Hence, $\mathrm{GABA}_{\mathrm{B}}$ receptors can function as variable modulators of the piriform circuit, with the outcome depending upon the balance of inhibitory and disinhibitory mechanisms they engage.

\section{MATERIALS AND METHODS}

\section{Animals}

All animal housing, breeding and surgical procedures were approved by the Animal Experimentation Ethics Committee of the Australian National University and conform to the guidelines of the National Health and Medical Research Council of Australia. Experiments used heterozygous GAD67-GFP ( $\Delta$ neo) mice of either sex bred on a C57BL6/J background.

\section{Slice Electrophysiology}

Experiments used acute brain slices (300 $\mu \mathrm{m}$ thick) prepared from 16-day to 26-day-old mice using standard methods as previously described (Suzuki and Bekkers, 2006). Briefly, mice were deeply sedated with isoflurane (2.5\% in oxygen), decapitated, and the brain immediately removed and submerged in ice-cold cutting solution (in mM: $125 \mathrm{NaCl}, 3 \mathrm{KCl}$, $25 \mathrm{NaHCO}_{3}, 1.25 \mathrm{NaH}_{2} \mathrm{PO}_{4}, 0.5 \mathrm{CaCl}_{2}, 6 \mathrm{MgCl}_{2}, 10$ glucose, 1.5 (+)-sodium L-ascorbate, 2.25 sodium pyruvate and saturated with $95 \% \mathrm{O}_{2} / 5 \% \mathrm{CO}_{2}$ ). Coronal slices containing the anterior PC were cut using a Vibroslice (Campden Instruments) and incubated in artificial cerebrospinal fluid (ACSF, in $\mathrm{mM}$ : $125 \mathrm{NaCl}, 3 \mathrm{KCl}, 25 \mathrm{NaHCO}_{3}, 1.25 \mathrm{NaH}_{2} \mathrm{PO}_{4}, 2 \mathrm{CaCl}_{2}, 1 \mathrm{MgCl}_{2}$, 25 glucose, bubbled with $95 \% \mathrm{O}_{2} / 5 \% \mathrm{CO}_{2}$ ) at $35{ }^{\circ} \mathrm{C}$ for $45 \mathrm{~min}$, then at room temperature until required.

For electrophysiological recordings, slices were transferred to a recording chamber and continuously superfused $(2-3 \mathrm{ml} / \mathrm{min})$ with warmed $\left(31 \pm 1.5^{\circ} \mathrm{C}\right)$ ACSF. Infrared-differential interference contrast microscopy (Olympus BX50WI) was used to make visualized whole-cell patch clamp recordings from layer 2 principal neurons in the PC. The two main classes of these neurons, SL and SP cells, were identified by their characteristic electrical properties and laminar location (Suzuki and Bekkers, 2011). Recording electrodes were glass pipettes with a resistance of 5-7 M $\Omega$ when filled with (in $\mathrm{mM}$ ) $135 \mathrm{KMeSO}_{4}$, $7 \mathrm{NaCl}, 10 \mathrm{HEPES}, 0.1$ EGTA, $2 \mathrm{MgCl}_{2}, 1 \mathrm{Na}_{2} \mathrm{ATP}, 0.3 \mathrm{Na}_{3} \mathrm{GTP}$, 10 sorbitol adjusted to $\mathrm{pH} 7.2$ with $\mathrm{KOH}$. In experiments in which IPSCs were recorded, $135 \mathrm{CsMeSO}_{4}$ replaced $\mathrm{KMeSO}_{4}$ to block $\mathrm{K}^{+}$channels. Data were obtained using a Multiclamp 700A amplifier (Molecular Devices), filtered at $10 \mathrm{kHz}$ and digitized at 20 or $50 \mathrm{kHz}$ by an ITC-18 interface (Instrutech/HEKA) under the control of Axograph (Axograph Scientific). Unless otherwise stated, current clamp recordings were done at the resting potential of the neuron (SP: $-80.3 \pm 6.7 \mathrm{mV}, n=90$; SL: $-61.3 \pm 0.7 \mathrm{mV}, n=43$ ), and the voltage clamp recordings were done with the soma holding potential at $-70 \mathrm{mV}$. Pipette capacitance was neutralized and the series resistance compensated in current clamp with the bridge balance circuit. No liquid junction potential correction was applied.

Focal extracellular synaptic stimulation of the PC was done using an isolated stimulator (Digitimer DS2) that delivered $100 \mu \mathrm{s}$ long constant-voltage pulses with an adjustable amplitude. Stimuli were delivered at $20 \mathrm{~s}$ intervals. The stimulating electrode was constructed from a low resistance 
patch electrode (tip diameter 5-10 $\mu \mathrm{m}$ ) filled with ACSF and coated with electrically-conductive paint. The stimulus current was passed between the filling solution and a wire connected to the paint; hence, this functioned as a concentric bipolar stimulating electrode (Bekkers and Clements, 1999). The tip of the stimulating electrode was placed in different layers (layer $1 \mathrm{a}, 1 \mathrm{~b}, 2$ or 3 ) by reference to established neuroanatomical landmarks (Suzuki and Bekkers, 2011) in order to achieve layerspecific stimulation. The tip was always at least $65 \mu \mathrm{m}$ away from the recorded soma to avoid direct stimulation of the neuron.

ACSF was supplemented with picrotoxin $(100 \mu \mathrm{M})$ to block $\mathrm{GABA}_{\mathrm{A}}$ receptors, plus 2,3,4-tetrahydro-7-nitro-2,3dioxoquinoxaline-6-carbonitrile disodium (CNQX; $10 \mu \mathrm{M})$ and D-2-amino-5-phosphonopentanoic acid (D-APV; $50 \mu \mathrm{M})$ to block glutamate receptors when recording postsynaptic $G_{A B A}$ responses. EPSCs were recorded in the absence of CNQX and $\mathrm{D}-\mathrm{APV}$, and IPSCs were recorded in the absence of picrotoxin. Prior to recording IPSCs, the soma was clamped at $0 \mathrm{mV}$ in voltage clamp to increase the driving force for $\mathrm{Cl}^{-}$ions.

\section{In Vivo Two-Photon Calcium Imaging and LFP Recording}

Surgical procedures for exposing the anterior PC and conducting two-photon microscopy were performed as described previously (Tantirigama et al., 2017). Briefly, mice (50-70 days-old) were anesthetized using a cocktail of chlorprothixene $(5 \mathrm{mg} / \mathrm{kg})$, urethane $(0.7 \mathrm{~g} / \mathrm{kg})$ and atropine $(0.2 \mathrm{mg} / \mathrm{kg})$ delivered subcutaneously. Skin incisions were treated with a local anesthetic (prilocaine, $0.2 \mathrm{mg} / \mathrm{kg}$ ). The depth of anesthesia was monitored throughout the experiment; when necessary, a top-up dose of urethane $(10 \%-30 \%$ of the initial dose) was given. Body temperature was maintained at $36-37^{\circ} \mathrm{C}$ using a heating blanket. A craniotomy $(\sim 1.5 \times 1.5 \mathrm{~mm})$ was opened over the region where the middle cerebral artery and the dorsal aspect of the lateral olfactory tract (LOT) intersect, and the dura was removed. Using dental cement (Paladur, Heraeus) a headpost was attached to the skull for head-fixation and then a water-tight chamber was constructed around the surgical site to accommodate the water-immersion objective. The chamber was filled with Ringer's solution containing (mM) $135 \mathrm{NaCl}, 5.4 \mathrm{KCl}, 1.8 \mathrm{CaCl}_{2}, 1 \mathrm{MgCl}_{2}, 5 \mathrm{HEPES}$ at $\mathrm{pH}$ 7.4. The calcium indicator dye Cal-520 AM (1 mM; AAT Bioquest) was pressure-injected into the PC at a depth of 200-300 $\mu \mathrm{m}$ with a micropipette. Sulforhodamine (SR) 101 (50 $\mu \mathrm{M})$ was added to the Cal-520 solution to label astrocytes. Calcium imaging was performed at least $30 \mathrm{~min}$ after dye loading.

A piece of No. 0 glass coverslip was cut to fit over the craniotomy and glued in place. Imaging was done using a Thorlabs two-photon microscope with a $16 \times$ water immersion objective (Nikon, $0.8 \mathrm{NA}$ ), resonant-galvanometer scanners, and a Ti:Sapphire laser (Chameleon Ultra, Coherent) running at $810 \mathrm{~nm}$. The $\mathrm{x}-\mathrm{y}$ image scanning plane was either a $300 \times 300 \mu \mathrm{m}$ $(512 \times 512$ pixels $)$ or a $300 \times 150 \mu \mathrm{m}(512 \times 256$ pixels $)$ frame, and time-series movies were captured at 30 or 60 frames per second, respectively. SL and SP cells were distinguished by their laminar location and depth from the pial surface (SL: layer $1 \mathrm{~b} / 2 \mathrm{a}$ border, $160-210 \mu \mathrm{m}$ deep; SP: layer $2 \mathrm{~b} / 3$ border, 250-300 $\mu \mathrm{m}$ deep).

Local field potential (LFP) recordings were done using patch pipettes (1-4 M $\Omega$ ) filled with Ringer solution positioned in layer 2 of PC at a $30^{\circ}$ angle and a depth of 200-300 $\mu \mathrm{m}$. Recordings were filtered at $800 \mathrm{~Hz}$ and digitized at $5 \mathrm{kHz}$ by using a Multiclamp 200B amplifier (Molecular Devices) and an ITC-18 interface. Respiration was monitored using a piezoelectric strap around the chest.

\section{Data Analysis}

Electrophysiology analysis was done using Axograph. Latency to first AP was defined as the time from the beginning of current ramp to the peak of the first AP. The synapticallyevoked responses shown in the figures and used for analysis were averages of 4-10 individual episodes (see figure legends). The peak of the postsynaptic $\mathrm{GABA}_{\mathrm{B}}$ receptor-mediated response was found by averaging the voltage or current during a window of length $20 \mathrm{~ms}$ (Figure 1) or $50 \mathrm{~ms}$ (Figures 2A,B), centered around the peak synaptic response relative to baseline. The baseline was adjusted over a $50 \mathrm{~ms}$ window preceding the first stimulus. Analysis of EPSCs and IPSCs was similar, except that the peak was measured over a 1-3 ms window and the baseline was adjusted over a 5 or $20 \mathrm{~ms}$ window, respectively. The paired-pulse ratio (PPR) of synaptic currents was calculated as the amplitude of the second or third current divided by that of the first.

Fluorescence changes in calcium imaging data were analyzed with Image ${ }^{1}$ and custom MATLAB code (MathWorks). Images in each time-series movie were registered using the ImageJ plugin Turboreg, and regions of interest (ROIs) were drawn manually for each individual soma (excluding astrocytes labeled with SR 101) in the average registered image. The raw fluorescence intensity of each ROI was calculated and expressed as $\Delta \mathrm{F} / \mathrm{F}_{0}=\left(\mathrm{F}-\mathrm{F}_{0}\right) / \mathrm{F}_{0}$, where $\mathrm{F}_{0}$ is the median of the lower $80 \%$ of values. Transients in the $\Delta \mathrm{F} / \mathrm{F}_{0}$ trace were detected using a sliding template and converted to spike rate as described previously (Tantirigama et al., 2017). All analysis was done using unfiltered traces, but a moving-average threepoint filter was used to smooth the traces shown in the figures.

\section{Statistical Analysis}

Statistical analysis was done using Prism 6.0 (GraphPad) and $\mathrm{R}^{2}$. Comparisons used linear mixed effects regression models, analysis of variance (ANOVA) or the 2-tailed $t$-test, where appropriate and as indicated. Linear models were calculated using the lmer package in $\mathrm{R}$ by testing the relationship between variables, and included both fixed effects (such as amplitude or drug) and random effects (such as inter-neuron variation), avoiding pseudo-replication. A $t$-test on the coefficient of fitted linear regression was used to assess whether the coefficient

\footnotetext{
${ }^{1}$ https://imagej.nih.gov/ij/

${ }^{2}$ https://www.r-project.org/
} 


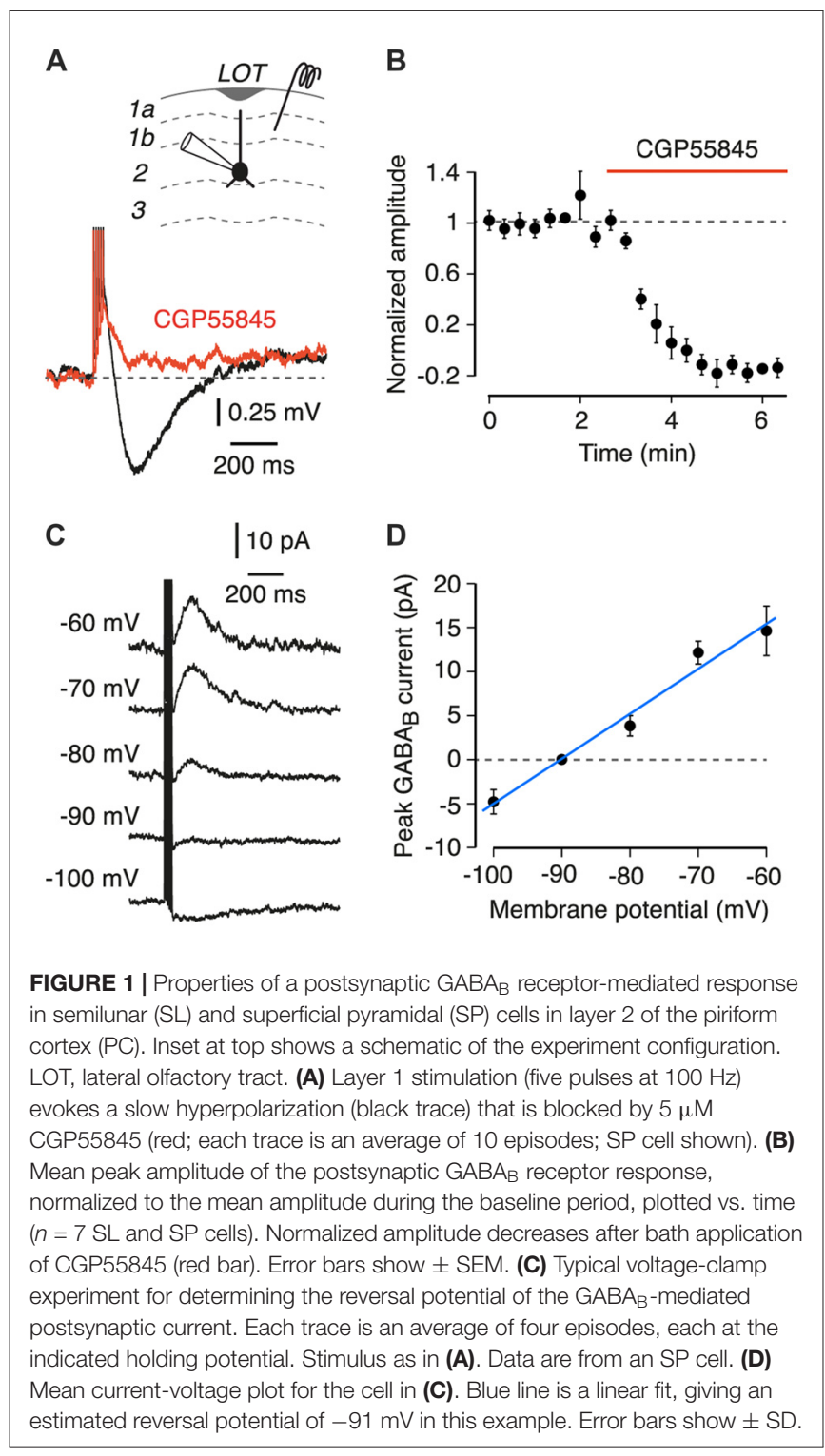

was significantly different from zero. Data from SL and SP cells were combined if statistical analysis indicated that there were no cell-type dependent effects, with the exception of Figure 4, in which the analysis was run separately for SL and SP cells.

\section{RESULTS}

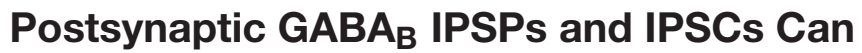 Be Elicited in SL and SP Cells}

We searched for postsynaptic $G_{A B A}$ receptor responses by applying a 5-pulse $100 \mathrm{~Hz}$ extracellular electrical stimulus to layer 1a while recording from an identified SL or SP cell. The bath solution contained $10 \mu \mathrm{M}$ CNQX, $25 \mu \mathrm{M}$ $\mathrm{D}-\mathrm{APV}$ and $100 \mu \mathrm{M}$ picrotoxin to block AMPA, NMDA and $\mathrm{GABA}_{\mathrm{A}}$ receptors, respectively. Recordings in current

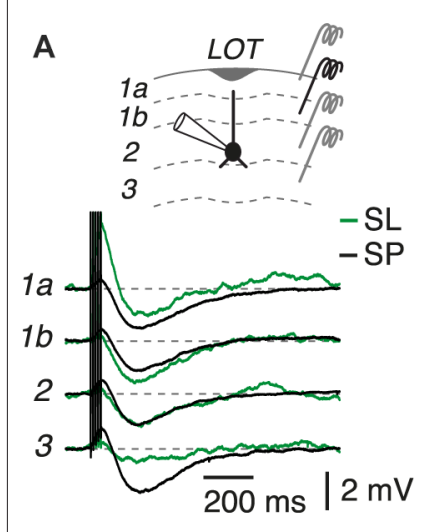

C

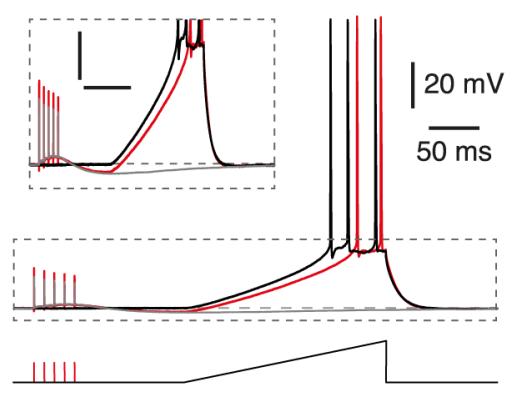

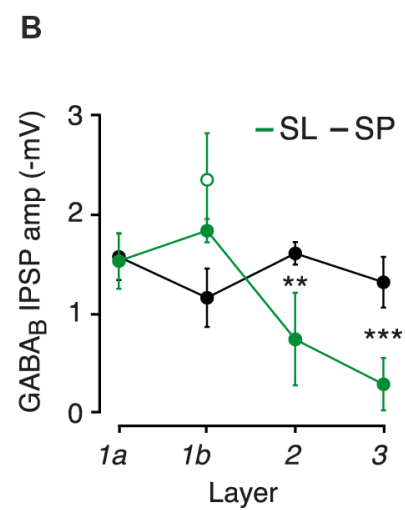

D

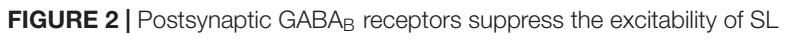
and SP cells. (A) Typical GABA $A_{B}$ receptor-mediated postsynaptic potentials in an SL cell (green) and an SP cell (black) resulting from 5-pulse $100 \mathrm{~Hz}$ stimuli applied in the layer indicated at left. Each trace is an average of four episodes. Inset shows a schematic of the experiment configuration, with the different stimulator locations indicated. (B) Mean peak postsynaptic GABA IPSP plotted against layer number for SL cells (green; $n=3$ ) and SP cells (black; $n=5)$. Green open symbol shows the mean bracketing response of SL cells to layer $1 \mathrm{~b}$ stimulation at the end of the experiment, confirming absence of run-down. Error bars show \pm SEM. (C) Typical result from an experiment in which a depolarizing current ramp was applied in the absence (black trace) or presence (red trace) of a preceding 5 -pulse $100 \mathrm{~Hz}$ stimulus train to elicit a postsynaptic $G A B A_{B}$ receptor response. Gray trace shows the $G A B A_{B}$ receptor response without the current ramp. Data are from an SP cell. Region in the dashed box is shown expanded in the inset. Scale bars for inset: $10 \mathrm{mV}$, $100 \mathrm{~ms}$. (D) Summary data for experiments like in (C) showing that prior activation of postsynaptic $G_{A B A}$ receptors increases the latency to the first action potential (AP) fired in response to the current ramp. CON, control. Combined data from $n=5 \mathrm{SL}$ and SP cells. $n s$, not significant; * $p<0.05$; ${ }^{* *} p<0.01 ;{ }^{* * *} p<0.001$.

clamp mode revealed a fast depolarization followed by a slow hyperpolarization which peaked at $185 \pm 0.01 \mathrm{~ms}$ and had an average amplitude of $1.34 \pm 0.08 \mathrm{mV}(n=7$, combined data from SL and SP cells, no significant difference between cell types, $p=0.6$, linear mixed effects model; Figure 1A, black trace). This hyperpolarization was blocked by the $\mathrm{GABA}_{\mathrm{B}}$ receptor antagonist CGP55845 (5 $\mu$ M; Figure 1A, red trace). The block was quantified by plotting the mean normalized amplitude of the hyperpolarization vs. time (Figure 1B). CGP55845 significantly reduced the normalized amplitude to $-0.02 \pm 0.06(n=7$, $p<0.001$, linear mixed effects model), suggesting that the hyperpolarization was due to $\mathrm{GABA}_{\mathrm{B}}$ receptor activation. The small, fast depolarization preceding the $\mathrm{GABA}_{\mathrm{B}}$ response was 


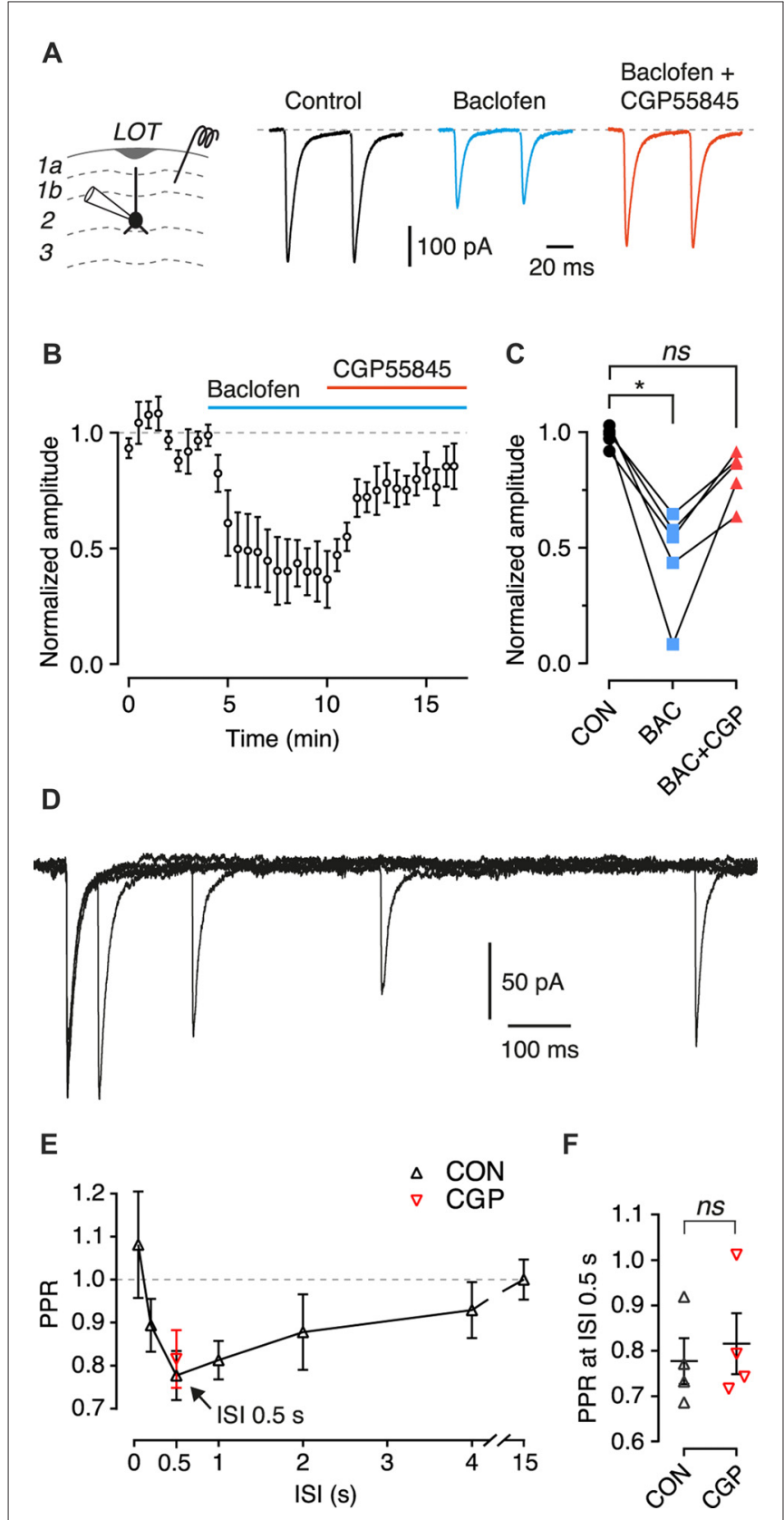

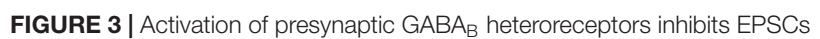
from associational inputs onto SP cells, but these receptors are not involved in paired-pulse depression. (A) Typical EPSCs recorded in an SP cell in response to paired-pulse stimulation (50 ms interstimulus interval, ISI) of layer $1 \mathrm{~b}$ during control (black), in the presence of baclofen (100 $\mu \mathrm{M}$; blue) and baclofen + CGP55845 (5 $\mu \mathrm{M}$; red). Each trace is an average of 10 episodes. Stimulus artifacts have been blanked. (B) Mean EPSC amplitude, normalized to the mean amplitude during the control period, plotted vs. time. Baclofen (bath applied during the period shown by the blue bar) decreased the normalized EPSC amplitude, and addition of CGP55845 (application shown by the red bar) reversed this inhibition. Error bars are \pm SEM. Data from $n=5$ SP cells. (C) Summary data for (B) showing the normalized EPSC amplitude averaged over the control period (CON, 100-190 s), the period in baclofen (BAC, 400-490 s) and the period in baclofen + CGP55845 (BAC+CGP, 800-890 s). Symbols show means for individual cells ( $n=5$ SP cells). (D) Typical data from

(Continued)
FIGURE 3 | Continued

an EPSC paired-pulse experiment with an SP cell and ISI 50, 200, 500 and $1000 \mathrm{~ms}$. Each trace is an average of five episodes. Stimulus artifacts have been blanked. (E) Mean paired-pulse ratio (PPR) plotted vs. ISI $(n=4 \mathrm{SP}$ cells). Arrow indicates the ISI with the smallest PPR (0.5 s). Black symbols show the mean PPR measured under control conditions; red symbol shows the mean PPR measured at $0.5 \mathrm{~s}$ ISI in the same cells in the presence of $5 \mu \mathrm{M}$ CGP55845 ( $n=4$ SP cells). Error bars show \pm SEM. (F) Summary data for (E) showing PPR at $0.5 \mathrm{~s} \mathrm{ISI} \mathrm{during} \mathrm{control}(\mathrm{CON})$ and in the presence of CGP55845 (CGP). Symbols show the mean for individual cells ( $n=4$ SP cells). Error bars show \pm SEM. $n s$, not significant; * $p<0.05$.

most likely due to incompletely blocked ionotropic glutamate receptors.

To confirm the identity of the slow hyperpolarization, the reversal potential of the underlying current was measured in voltage clamp mode (Figure 1C, example traces at a range of holding potentials, measured for an SP cell; Figure 1D, current-voltage plot for the same cell). Current-voltage plots gave an average reversal potential of $-91.9 \pm 1.4 \mathrm{mV}$ and an average conductance of $0.38 \pm 0.06 \mathrm{nS}(n=11$, combined data from SL and SP cells). The reversal potential is similar to the calculated Nernst potential for $\mathrm{K}^{+}$for our solutions $(-100 \mathrm{mV})$ and is consistent with the $\mathrm{GABA}_{\mathrm{B}}$ response being mediated by a $\mathrm{K}^{+}$-selective channel (Bettler et al., 2004)

\section{Layer-Specific Differences in Postsynaptic GABA $_{B}$ IPSPs in SL and SP Cells}

We next asked whether the size of the postsynaptic $G_{A B A}$ response depended on the layer to which stimulation was applied, and whether such differences might be cell-type dependent. We hypothesized that, since SL cells lack basal dendrites and SP cells do not (Suzuki and Bekkers, 2011), SL cells would show smaller $G_{A B A}$ synaptic responses when extracellular stimulation was applied to deeper layers (layers 2 and 3 ).

SP cells showed a consistent $\mathrm{GABA}_{\mathrm{B}}$ response which did not differ between layers (Figures 2A,B, black traces and symbols; $n=5, p>0.05$, ANOVA). In contrast, SL cells showed a significantly decreased response in deeper layers compared to that in SP cells (layer 2: $p=0.007$; layer 3: $p=0.0006$, ANOVA; $\mathrm{SP}, n=5 ; \mathrm{SL}, n=3)$. Hence, SL and SP cells receive similar $G_{A B A}$ input in layer 1 , but $S P$ cells receive stronger $G_{A B A}$ input in deeper layers, consistent with the known differences in dendritic morphology (Suzuki and Bekkers, 2011; Choy et al., 2017).

\section{Postsynaptic GABA IPSPs Reduce Excitability of Principal Cells}

The physiological consequence of activating postsynaptic $\mathrm{GABA}_{\mathrm{B}}$ receptors in SL and SP cells was assessed using a protocol in which a constant current ramp was used to initiate action potentials either with or without a preceding $\mathrm{GABA}_{\mathrm{B}}$ response (Figure 2C). The latency to the first action potential was significantly delayed in both SL and SP cells when a $\mathrm{GABA}_{\mathrm{B}}$ IPSP was present (Figure 2D; $p=0.014$, paired $t$-test, $n=5$, combined data from SL and 


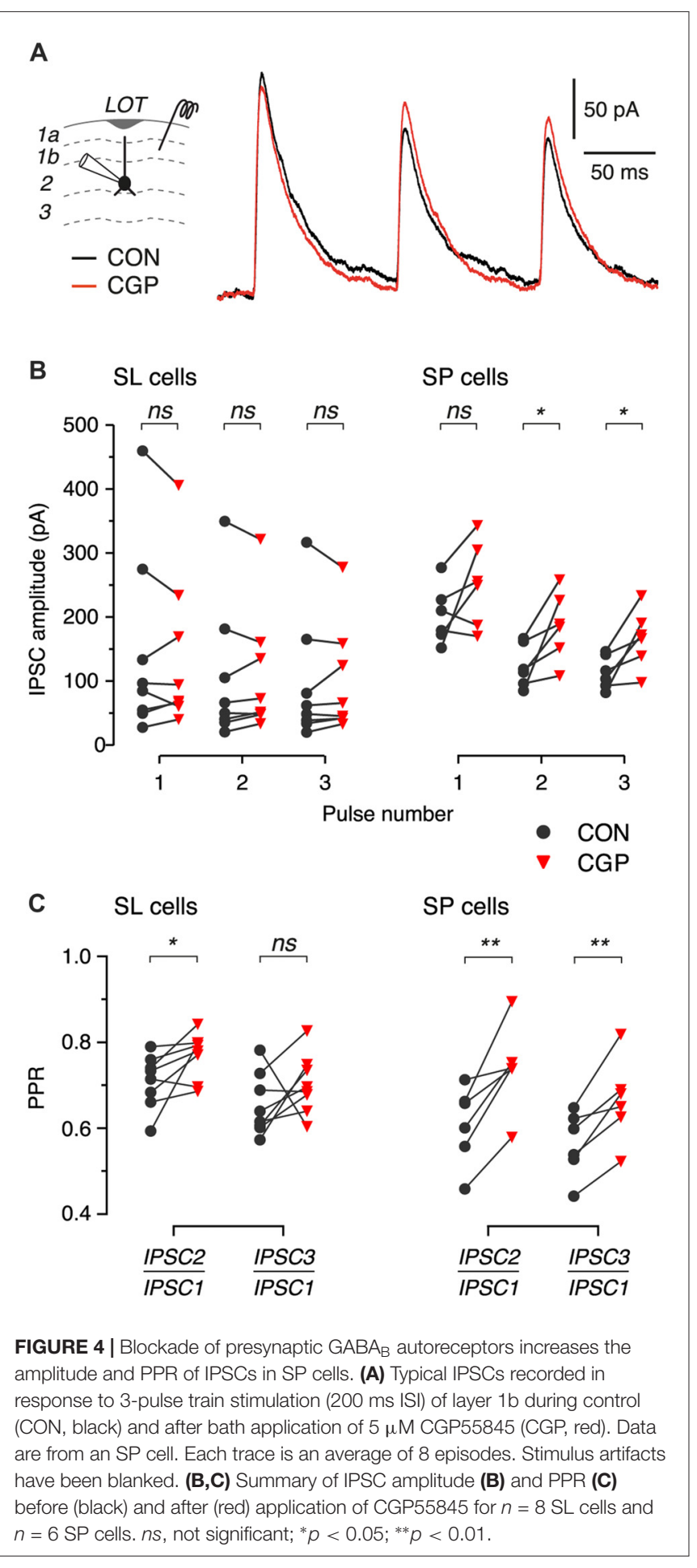

SP cells). Moreover, the number of action potentials was significantly reduced following $\mathrm{GABA}_{\mathrm{B}}$ receptor activation (control, $2.9 \pm 0.2 ; \mathrm{GABA}_{\mathrm{B}}, 2.3 \pm 0.2 ; p<0.001$, paired $t$-test, $n=5$, combined data from SL and SP cells). Thus, by several measures the intrinsic excitability of layer 2 principal cells is reduced by the prior occurrence of a $\mathrm{GABA}_{\mathrm{B}}$ IPSP.

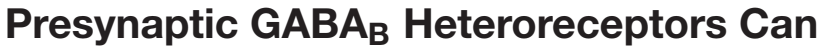
Suppress Associational EPSCs in SP Cells

We next turned to a study of presynaptic $G_{A B A} B$ receptors. EPSCs were recorded under voltage clamp in SP cells while applying paired extracellular electrical stimuli $(50 \mathrm{~ms}$ between stimulus pairs) to associational fibers in layer $1 \mathrm{~b}$ (Figure 3A). Bath perfusion of the $\mathrm{GABA}_{B}$ receptor agonist baclofen $(100 \mu \mathrm{M})$ caused a large decrease in the EPSC amplitude (Figures 3B,C; $p<0.05$; repeated measures ANOVA and Dunnett's post hoc test, $n=5$ ). This inhibition was partly reversed by CGP55845 (Figures 3B,C). The PPR of the EPSC amplitudes was significantly increased in the presence of baclofen (control: $0.96 \pm 0.05$; baclofen: $1.16 \pm 0.12$; $p=0.005,2$-tailed $t$-test, $n=5$ cells), indicating that the EPSC suppression has a presynaptic locus of expression. These results are consistent with previous reports (Tang and Hasselmo, 1994; Franks and Isaacson, 2005; Suzuki and Bekkers, 2011).

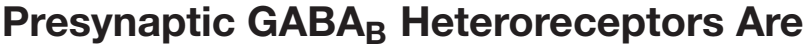 Not Involved in Paired-Pulse Depression of Associational EPSCs in SP Cells}

Having verified that exogenously applied baclofen can presynaptically inhibit associational EPSCs in SP cells, we next wished to examine the effects of presynaptic $G A B A_{B}$ receptor activation in a more physiological setting, without the use of baclofen. To do this, we designed a paired-pulse protocol in which the interstimulus interval (ISI) was randomly varied over a range of durations between $50 \mathrm{~ms}$ and $15 \mathrm{~s}$ (Figure 3D). Under control conditions a short ISI $(50 \mathrm{~ms})$ produced little paired-pulse facilitation or depression, consistent with the result in the previous section and earlier work (Suzuki and Bekkers, 2006). However, slightly longer ISIs (200 ms and $500 \mathrm{~ms}$ ) produced clear paired-pulse depression, with the response fully recovered at $15 \mathrm{~s}$ (Figure 3E).

We hypothesized that the depression at intermediate ISIs was due to the activation of $\mathrm{GABA}_{B}$ heteroreceptors: GABA released from inhibitory terminals during the first stimulus might diffuse to nearby excitatory terminals and presynaptically inhibit the EPSC response to the second stimulus. The slow timecourse of the depression might reflect the time required for diffusion and presynaptic suppression of glutamate release (Isaacson et al., 1993). This idea was tested by repeating the experiment in the presence of the $\mathrm{GABA}_{\mathrm{B}}$ receptor antagonist CGP55845 $(5 \mu \mathrm{M})$, which was predicted to reverse the depression at $500 \mathrm{~ms}$. Contrary to expectations, no significant difference was found before and after adding CGP55845 (Figure 3F; control: $0.81 \pm 0.03$; CGP: $0.76 \pm 0.02 ; p=0.69$, paired $t$-test, $n=4$ ). This result suggests that $\mathrm{GABA}_{\mathrm{B}}$ receptors do not mediate the paired-pulse depression observed at $500 \mathrm{~ms}$ with this protocol.

\section{Presynaptic GABA Autoreceptors Increase Short-Term Depression of IPSCs in SL and SP Cells}

Given that we were unable to reveal $\mathrm{GABA}_{\mathrm{B}}$ heteroreceptors on glutamate-releasing terminals in response to paired-pulse 
A

\section{Cal-520 SR101}

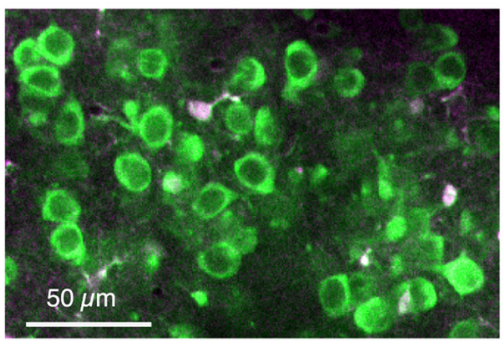

C

\section{Control}

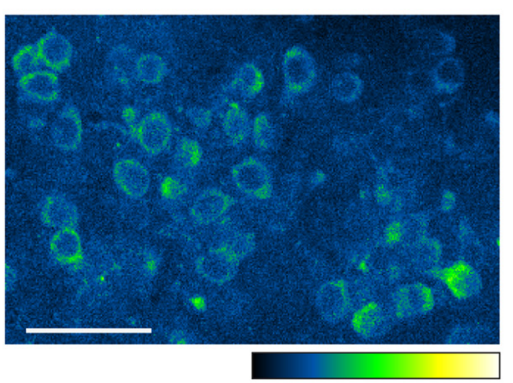

Fluorescence

E

\section{Epileptic (+baclofen)}

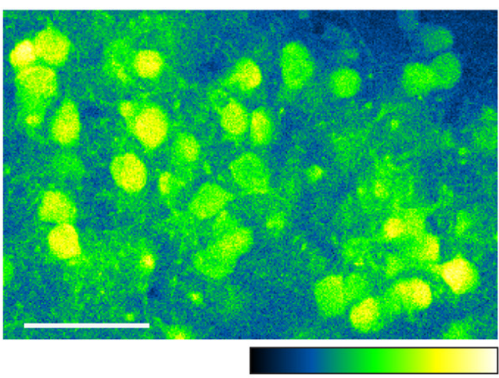

G

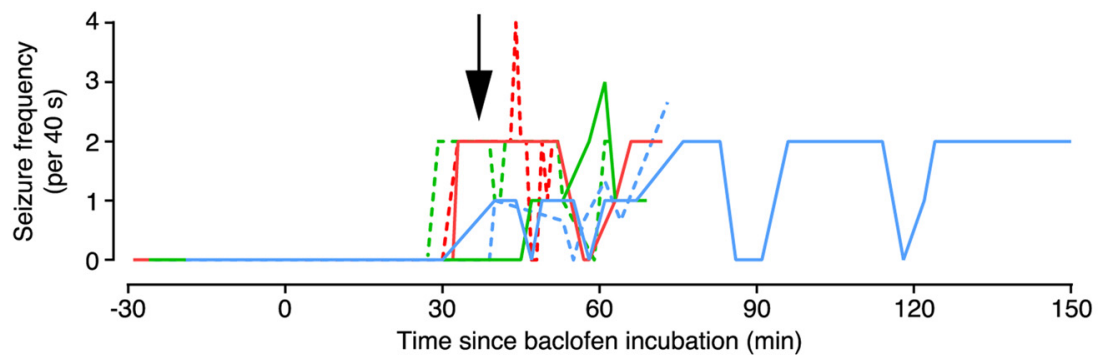

B

D

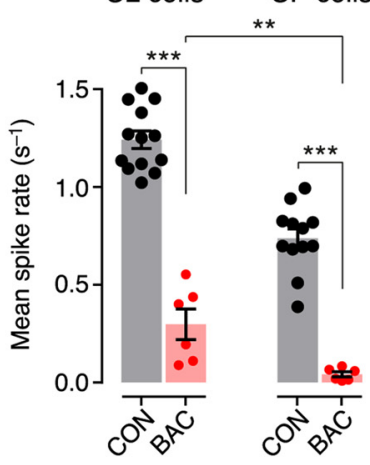

Control

$\mathrm{Ca}^{2+}$

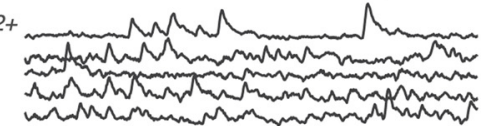

LFP

$11 \mathrm{mV}$

Resp

$\underline{2 s}$

H.whw.

F

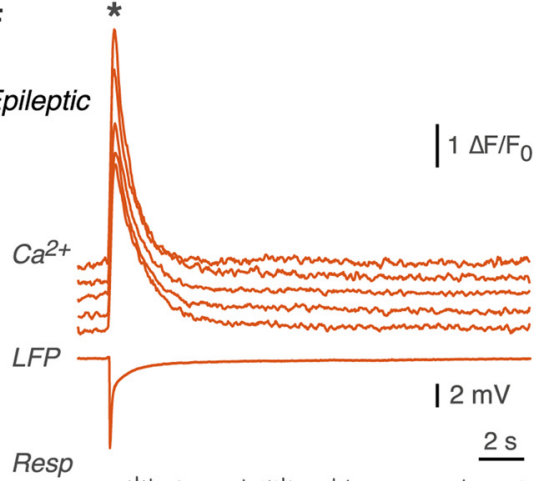

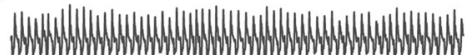

\section{$\underline{2 s}$}


electrical stimulation in slices, we wondered if similar or stronger stimuli might unmask $\mathrm{GABA}_{\mathrm{B}}$ autoreceptors on GABA-releasing terminals. We addressed this question by recording IPSCs in identified SL and SP cells while applying brief trains of extracellular stimuli to associational layers (three pulses with 200 ms ISIs; Figure 4A; extension of a protocol used by Kapur et al., 1997). IPSCs were isolated by pharmacologically blocking ionotropic glutamate receptors and by voltage-clamping the neurons at $0 \mathrm{mV}$ to increase the electrical driving force for $\mathrm{Cl}^{-}$ ("Materials and Methods" section). The trains of IPSCs were recorded before and after bath perfusion of CGP55845 (5 $\mu \mathrm{M})$ to block $\mathrm{GABA}_{\mathrm{B}}$ receptors.

We expected to see $\mathrm{GABA}_{\mathrm{B}}$ receptor-dependent effects on the later IPSCs in the train, due to activation of $G_{A B A}$ autoreceptors on the presynaptic GABAergic terminals. We did find such effects, which were more prominent in SP cells (Figure 4B). While the amplitude of the first IPSC in the train was not significantly affected by $\mathrm{GABA}_{\mathrm{B}}$ receptor blockade in either cell type (SL: $147.9 \pm 52.2 \mathrm{pA}$ in control, $142.5 \pm 44.4 \mathrm{pA}$ in CGP, $p=0.64$, linear model, $n=8$; SP: $203.3 \pm 18.5 \mathrm{pA}$ in control, $251.9 \pm 27.1$ in CGP, $p=0.12$, linear model, $n=6$ ), the amplitudes of the second and third IPSCs were significantly increased by CGP55845 in SP cells but not in SL cells (e.g., second IPSC; SL: $106.3 \pm 39.3 \mathrm{pA}$ in control, $109.1 \pm 34.4 \mathrm{pA}$ in CGP, $p=0.70$, linear model, $n=8$; SP: $123.9 \pm 13.8 \mathrm{pA}$ in control, $186.6 \pm 21.6$ in CGP, $p=0.025$, linear model, $n=6$ ). Furthermore, the presynaptic locus of this effect was confirmed by the significant increase in PPR in SP cells (Figure 4C, right). There was also a small but significant increase in this ratio for the first and second IPSCs in SL cells (Figure 4C, left). These findings suggest that synaptically released GABA can activate presynaptic $\mathrm{GABA}_{\mathrm{B}}$ autoreceptors on inhibitory terminals to suppress later IPSCs in a train, but the effect appears to be stronger at inhibitory synapses onto SP cells.

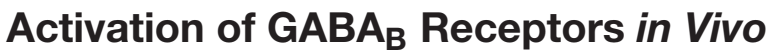 Both Suppresses and Enhances Network Activity in SL and SP Cells}

Our results so far have indicated that activation of $\mathrm{GABA}_{B}$ receptors can have both inhibitory and excitatory effects on neural circuits in the PC. On the one hand, activation of postsynaptic $\mathrm{GABA}_{\mathrm{B}}$ receptors inhibits firing in SL and SP cells (Figure 2), and presynaptic $\mathrm{GABA}_{\mathrm{B}}$ heteroreceptors are poised to inhibit glutamate release (Figure 3). Both of these effects are inhibitory. On the other hand, activation of presynaptic $\mathrm{GABA}_{\mathrm{B}}$ autoreceptors can reduce GABA release onto SP cells (Figure 4), thereby disinhibiting those cells and having an overall excitatory effect on the circuit. We wondered if both inhibitory and excitatory effects of $\mathrm{GABA}_{\mathrm{B}}$ receptor activation could be observed in the intact $\mathrm{PC}$ in vivo.

To address this question, we performed in vivo two-photon calcium imaging of identified SL and SP cells in the anterior PC of anesthetized mice before and after superfusing the cortical surface with the $\mathrm{GABA}_{\mathrm{B}}$ receptor agonist, baclofen $(500 \mu \mathrm{M})$. SL and SP cells, loaded with the calcium indicator Cal-520, were distinguished from each other by their cortical
FIGURE 5 | Continued

intensity. (D) Simultaneously recorded $\Delta \mathrm{F} / \mathrm{F}_{0}$ traces from five cells in the field in (C) showing spontaneous activity (top), the local field potential (LFP) recording (middle) and the respiration of the animal (bottom) under control conditions. (E) Same as in (C) but 36 min after baclofen was added to the superfusate. The image was taken at the time of the epileptic event indicated by the asterisk in (F). (F) Same as in (D), but after 36 min of baclofen. Note the large synchronous events seen in both the $\Delta F / F_{0}$ traces and the LFP trace. (G) Timecourse plot of the number of epileptic events observed in each $40 \mathrm{~s}$-long movie of calcium fluorescence vs. the time since baclofen was first applied to the cortical surface. Each colored line shows the timecourse plot for each of $n=6$ mice. Arrow indicates the mean latency to onset of the first seizure event, averaging across all mice. ${ }^{* *} p<0.01 ;{ }^{* * *} p<0.001$.

depth and from astrocytes by their exclusion of the glial marker SR101 (e.g., Figure 5A, showing SP cells). Under control conditions in the absence of baclofen, individual SL and SP somas exhibited random spontaneous calcium transients (Figures 5C,D, upper traces), each of which corresponds to the firing of $\geq 2$ action potentials (Tantirigama et al., 2017). As we have shown previously, this random firing is driven by spontaneous bottom-up input from the $\mathrm{OB}$ and is not synchronized to respiration (Figure 5D, bottom trace; Tantirigama et al., 2017).

Addition of baclofen $(500 \mu \mathrm{M})$ to the Ringer's solution bathing the exposed surface of the cortex quickly ( $<15 \mathrm{~min}$ ) suppressed the mean spontaneous firing rate in both SL cells and SP cells (Figure 5B; SL: control, $1.24 \pm 0.04 \mathrm{~s}^{-1}, n=13$ mice; baclofen, $0.30 \pm 0.08 \mathrm{~s}^{-1}, p<0.001$, unpaired $t$-test, $n=6$; SP: control, $0.74 \pm 0.05 \mathrm{~s}^{-1}, n=12$ mice; baclofen, $0.04 \pm 0.01 \mathrm{~s}^{-1}$, $p<0.001$, unpaired $t$-test, $n=6$ ). The baclofen-suppressed spontaneous firing rate was significantly smaller in SP cells compared to SL cells (Figure 5B; $p<0.01$, unpaired $t$-test). Thus, the initial effect of activating $\mathrm{GABA}_{\mathrm{B}}$ receptors with baclofen was to inhibit the overall excitability of the anterior PC by suppressing spontaneous spiking activity.

With more prolonged exposure to baclofen (>29 min), large synchronized calcium transients started to emerge within both the SL cell and SP cell populations (Figures 5E-G, upper traces; asterisk indicates the time point shown in Figure 5E). A local field potential (LFP) electrode inserted in the PC also registered a large electrical event corresponding to the synchronized calcium transient (Figure 5F, middle trace; compare with corresponding trace in Figure 5D before the emergence of synchronized activity). A timecourse plot showing the onset of synchronized activity after baclofen application (Figure 5G) indicates that epileptiform activity appeared after $37 \pm 6.5$ min (mean \pm SD, $n=6$ mice). This kind of hyperexcitability was never seen in control animals during long experiments $(>120 \mathrm{~min})$ in the absence of baclofen ( $n>50$ mice). Hence, extended exposure to baclofen causes stronger excitatory effects of $\mathrm{GABA}_{\mathrm{B}}$ receptor activation in vivo.

\section{DISCUSSION}

Modulation of neural activity by pre- and postsynaptic $\mathrm{GABA}_{\mathrm{B}}$ receptors has been reported in many brain areas (Bettler et al., 2004), including the PC (Neville and Haberly, 2004). In this 
article we have extended earlier findings by studying the effects of $\mathrm{GABA}_{B}$ receptor activation on identified subtypes of $\mathrm{PC}$ principal neurons (SL and SP cells) and by exploring some of the consequences of $\mathrm{GABA}_{\mathrm{B}}$ receptor activation in vivo.

We found that both SL and SP cells express postsynaptic $\mathrm{GABA}_{\mathrm{B}}$ receptors that generate a slow IPSP in response to synaptic stimulation (Figures $2 \mathbf{A}, \mathbf{B}$ ). In both cell types, the effect of this IPSP was to subtly suppress the probability of firing action potentials in the postsynaptic neuron (Figures 2C,D). We also confirmed earlier findings that pharmacological activation of presynaptic $\mathrm{GABA}_{\mathrm{B}}$ receptors on glutamatergic associationfiber terminals depressed EPSCs recorded in SL and SP cells (Figures 3A-C). However, we found no evidence for (quasi-) physiological activation of these $\mathrm{GABA}_{\mathrm{B}}$ receptors when using a paired-pulse stimulus protocol to try to produce heterosynaptic activation via spillover of GABA at least when measuring at ISI $=500 \mathrm{~ms}$ Figures 3D-F). On the other hand, we did find evidence for a presynaptic $\mathrm{GABA}_{\mathrm{B}}$ autoreceptor-mediated modulation of IPSCs when using a triple-pulse stimulus protocol (Figure 4). This effect appeared to be more prominent in SP cells (Figures 4B,C). Finally, we found that local in vivo application of the $\mathrm{GABA}_{\mathrm{B}}$ agonist, baclofen, had a bimodal effect: initially, baclofen inhibited spontaneous spiking activity in SL and SP cells, and then later it caused synchronous epileptiform excitation (Figure 5). These in vivo observations may suggest that different $\mathrm{GABA}_{\mathrm{B}}$-mediated effects-first inhibitory, later excitatory-may be progressively engaged as the agonist diffuses deeper into the intact PC (see below). Overall, our findings highlight that $G_{A B A}$ receptors can function as potent modulators of the balance between excitation and inhibition in the piriform circuit.

It is important to maintain a distinction between SL and SP cells because we and others have shown that these cell types are morphologically, genetically and functionally distinctive, and so are likely to play different roles in the operation of the PC (Haberly, 1983; Suzuki and Bekkers, 2006, 2011; Wiegand et al., 2011; Carceller et al., 2016; Choy et al., 2017; Tantirigama et al., 2017). Previous work on $\mathrm{GABA}_{\mathrm{B}}$ receptors in the PC, however, has often neglected to maintain this distinction between subtypes of layer 2 principal cells. For example, an early report described a slow IPSC in generic layer 2 pyramidal cells, probably mediated by postsynaptic $\mathrm{GABA}_{\mathrm{B}}$ receptors (Tseng and Haberly, 1988). Here we found that SL and SP cells receive similar $G_{A B A}$ IPSCs when the stimulator is in layer 1 , but the $\mathrm{GABA}_{\mathrm{B}}$ IPSC amplitude in SL cells falls off dramatically when stimulating in deeper layers (Figures $\mathbf{2 A}, \mathbf{B}$ ). This finding is consistent with the lack of basal dendrites in SL cells (Suzuki and Bekkers, 2011; Choy et al., 2017). Interestingly, our estimate of the conductance of $\mathrm{GABA}_{B}$ IPSCs with layer 1 stimulation (about $0.4 \mathrm{nS}$ ) is smaller than the conductance found in hippocampal pyramidal cells under similar stimulation conditions (0.9-1.5 nS; Otis et al., 1993; Ling and Benardo, 1994), suggesting that this form of slow inhibition is less significant for the PC.

Presynaptic $\mathrm{GABA}_{\mathrm{B}}$ receptors on excitatory terminals have previously been shown to be restricted to associational (intracortical) inputs onto generic layer 2 principal cells; they are not found on afferent inputs from the OB (Tang and Hasselmo, 1994; Franks and Isaacson, 2005). More recently we confirmed that SL and SP cells both follow the same rule (Suzuki and Bekkers, 2011). However, all of these studies used exogenous baclofen to activate the presynaptic $\mathrm{GABA}_{\mathrm{B}}$ receptors (as in Figures 3A-C). Our observation of a slow paired-pulse depression of EPSCs at associational inputs onto SP cells (Figures 3D,E) lead us to wonder if this depression could be explained by spillover of endogenous GABA from nearby inhibitory terminals (as in the hippocampus; Isaacson et al., 1993). Surprisingly, blockade of $\mathrm{GABA}_{\mathrm{B}}$ receptors had no effect when assayed at $500 \mathrm{~ms}$ ISI (Figures 3E,F). It is possible that the depression is due to presynaptic metabotropic glutamate receptors (mGluRs) acting as autoreceptors (Baskys and Malenka, 1991; Billups et al., 2005; Jones et al., 2008). This possibility could be tested pharmacologically in future work. It is also possible that a different stimulus protocol might unmask other forms of short-term plasticity that do depend on $\mathrm{GABA}_{\mathrm{B}}$ receptors, and this would need to be explored in future experiments.

The presence of presynaptic $\mathrm{GABA}_{\mathrm{B}}$ receptors on inhibitory terminals in the $\mathrm{PC}$ has previously been inferred from experiments in which a slow component of the $\mathrm{GABA}_{\mathrm{A}}$-mediated IPSC in layer 2 principal cells was shown to be inhibited by baclofen (Kapur et al., 1997). The paired-pulse depression exhibited by this slow component was also preferentially reduced by a $\mathrm{GABA}_{\mathrm{B}}$ receptor antagonist (Kapur et al., 1997), similar to our finding (Figure 4) except that we measured the peak amplitude of the IPSC rather than a slow component. The slow $\mathrm{GABA}_{\mathrm{A}}$ IPSC identified in the earlier study might arise from neurogliaform cells, which are known to generate $\mathrm{GABA}_{\mathrm{A}}$ IPSCs with slow kinetics and which are reported in the neocortex and hippocampus to be inhibited following activation of presynaptic GABA $\mathrm{B}_{\mathrm{B}}$ autoreceptors (Tamás et al., 2003; Price et al., 2008; Oláh et al., 2009). We have previously shown that neurogliaform cells are common in the PC and profusely innervate SL and SP cells (Suzuki and Bekkers, 2012). It is possible that, under our stimulation conditions, the $\mathrm{GABA}_{\mathrm{A}}$ IPSCs comprised a larger input from neurogliaform cells than was the case in the earlier study (Kapur et al., 1997), allowing us to observe $\mathrm{GABA}_{\mathrm{B}}$ receptor-mediated modulation of the peak response rather than just a slow component. Our observation that this modulation is more prominent in SP cells, and may be absent in SL cells (Figure 4), is surprising. Future experiments would need to confirm and extend this finding. It should be noted that SL and SP cells do differ in other ways with regard to their synaptic properties (Suzuki and Bekkers, 2006 , 2011), so it is plausible that more prominent $\mathrm{GABA}_{B}$ modulation of GABA IPSCs in SP cells is another point of difference.

The slow shift from suppression to excitation we observed when locally applying baclofen in vivo (Figure 5) was surprising to us. $\mathrm{GABA}_{\mathrm{B}}$ receptor activation is often associated with anticonvulsant action; indeed, the $\mathrm{GABA}_{\mathrm{B} 1}$ knockout mouse exhibits spontaneous seizures (Schuler et al., 2001). However, baclofen has also been reported to induce seizures in patients (Schuele et al., 2005) and in animal models (Dugladze et al., 
2013), evidently in a concentration-dependent manner. Thus, the role of baclofen and $\mathrm{GABA}_{\mathrm{B}}$ receptors in hyperexcitability remains uncertain (Bettler et al., 2004).

Our current working hypothesis is that the biphasic effect of baclofen we observe is related to layer-specific modulation as the baclofen diffuses in from the surface. The most superficial layer, layer 1a, contains the dendrites of SL and SP cells that express postsynaptic $\mathrm{GABA}_{\mathrm{B}}$ receptors (Figure $2 \mathrm{~B}$ ), so baclofen in layer 1a will hyperpolarize these cells, presumably contributing to the early suppression of spontaneous action potentials (Figure 5B). Layer 1a also contains the input fibers from the $\mathrm{OB}$, but presynaptic terminals on these fibers do not express $\mathrm{GABA}_{\mathrm{B}}$ receptors (Tang and Hasselmo, 1994; Franks and Isaacson, 2005; Suzuki and Bekkers, 2011). However, as baclofen diffuses down to the next layer, layer $1 \mathrm{~b}$, it encounters associational fibers that do express presynaptic $\mathrm{GABA}_{\mathrm{B}}$ receptors (Tang and Hasselmo, 1994; Franks and Isaacson, 2005; Suzuki and Bekkers, 2011). Baclofen-mediated suppression of glutamate release from associational terminals will inhibit intracortical recurrent excitation (Poo and Isaacson, 2011), further suppressing spontaneous activity in layer 2 principal cells (Figure 5B). As it diffuses deeper, baclofen will continue to inhibit associational fibers in layers 2 and 3. However, the baclofen also increasingly encounters the GABAergic terminals of deeper interneurons, notably fast-spiking basket cells which potently inhibit the perisomatic region of SL and SP cells (Suzuki and Bekkers, 2010a,b). Assuming that the terminals of fast-spiking cells in the $\mathrm{PC}$ express $\mathrm{GABA}_{\mathrm{B}}$ receptors, activation of these receptors will suppress feedback inhibition of SL and SP cells and have a disinhibitory effect, unleashing epileptiform activity (Figures 5E-G). Such a consequence is consistent with the fact that the $\mathrm{PC}$ is one of the most epileptogenic regions in the brain, on a par with the hippocampus (Vaughan and Jackson, 2014; Vismer et al., 2015). Of course, it remains possible that there are other explanations for this biphasic effect of baclofen in vivo, and these would need to be examined in future work.

Baclofen has been used to selectively silence associational connections in the PC in vivo in order to study the importance of these connections for odor processing (Poo and Isaacson, 2011). Epileptic activity was not mentioned in that report. Care must be taken when interpreting such data, given that both excitatory and inhibitory synapses are likely to be perturbed by baclofen.

\section{REFERENCES}

Andrade, R., Malenka, R. C., and Nicoll, R. A. (1986). A G protein couples serotonin and $G A B A_{B}$ receptors to the same channels in hippocampus. Science 234, 1261-1265. doi: 10.1126/science.2430334

Baskys, A., and Malenka, R. C. (1991). Agonists at metabotropic glutamate receptors presynaptically inhibit EPSCs in neonatal rat hippocampus. J. Physiol. 444, 687-701. doi: 10.1113/jphysiol.1991.sp018901

Bekkers, J. M., and Clements, J. D. (1999). Quantal amplitude and quantal variance of strontium-induced asynchronous EPSCs in rat dentate granule neurons. J. Physiol. 516, 227-248. doi: 10.1111/j.1469-7793.1999.227aa.x

Bekkers, J. M., and Suzuki, N. (2013). Neurons and circuits for odor processing in the piriform cortex. Trends Neurosci. 36, 429-438. doi: 10.1016/j.tins.2013. 04.005
What might be the functional roles of $\mathrm{GABA}_{\mathrm{B}}$ receptors in the PC? Blockade of these receptors has been shown to have consequences for odor discrimination in the $\mathrm{PC}$ of rodents (Poo and Isaacson, 2011) and in the homologous region in insects (Riffell et al., 2014). It has also been reported that $\mathrm{GABA}_{\mathrm{B}}$ receptor-mediated presynaptic inhibition at excitatory synapses in the rat PC is enhanced after the animals learn a complex olfactory-discrimination task (Kfir et al., 2014). It was proposed that this enhancement might be a homeostatic adaptation to prevent uncontrolled activity after learning-induced increases in excitability (Kfir et al., 2014). Given the diverse effects of GABA receptor activation in neural circuits (Bettler et al., 2004), it is likely that additional roles of these receptors in olfaction remain to be discovered.

In conclusion, by using a combination of in vivo and in vitro approaches, we have provided further evidence that $G_{A B A}$ receptors are key players in the maintenance of balanced circuit behavior in the PC. By potently regulating membrane potential and neurotransmitter release, $\mathrm{GABA}_{\mathrm{B}}$ receptors can function as variable modulators of complex neural processing.

\section{AUTHOR CONTRIBUTIONS}

LBG and MLST are joint first authors on the article and performed the experiments. MLST and JMB conceived the project and designed the experiments. LBG, MLST and JMB did the analysis and wrote the manuscript.

\section{FUNDING}

This work was supported by the National Health and Medical Research Council of Australia (Project Grants 1050832 and 1128320 to JMB), by recurrent funding from the John Curtin School of Medical Research (JCSMR) to JMB, and by a JCSMR Honours scholarship to LBG.

\section{ACKNOWLEDGMENTS}

We are grateful to Dr. Norimitsu Suzuki for his suggestions for experiments, notably the one in Figure 3D. We also thank Dr. Teresa Neeman (ANU Statistical Consulting Unit) for her assistance with statistical analysis. Garry Rodda provided excellent technical support.

Bettler, B., Kaupmann, K., Mosbacher, J., and Gassmann, M. (2004). Molecular structure and physiological functions of $\mathrm{GABA}_{\mathrm{B}}$ receptors. Physiol Rev. 84, 835-867. doi: 10.1152/physrev.00036.2003

Billups, B., Graham, B. P., Wong, A. Y., and Forsythe, I. D. (2005). Unmasking group III metabotropic glutamate autoreceptor function at excitatory synapses in the rat CNS. J. Physiol. 565, 885-896. doi: 10.1113/jphysiol.2005. 086736

Carceller, H., Rovira-Esteban, L., Nacher, J., Castrén, E., and Guirado, R. (2016). Neurochemical phenotype of Reelin immunoreactive cells in the piriform cortex layer II. Front. Cell. Neurosci. 10:65. doi: 10.3389/fncel.2016.00065

Choy, J. M., Suzuki, N., Shima, Y., Budisantoso, T., Nelson, S. B., and Bekkers, J. M. (2017). Optogenetic mapping of intracortical circuits originating from semilunar cells in the piriform cortex. Cereb. Cortex 27, 589-601. doi: $10.1093 /$ cercor/bhv258 
Dugladze, T., Maziashvili, N., Börgers, C., Gurgenidze, S., Häussler, U., Winkelmann, A., et al. (2013). GABA $B$ autoreceptor-mediated cell type-specific reduction of inhibition in epileptic mice. Proc. Natl. Acad. Sci. U S A 110, 15073-15078. doi: 10.1073/pnas.1313505110

Franks, K. M., and Isaacson, J. S. (2005). Synapse-specific downregulation of NMDA receptors by early experience: a critical period for plasticity of sensory input to olfactory cortex. Neuron 47, 101-114. doi: 10.1016/j.neuron.2005. 05.024

Gottfried, J. A. (2010). Central mechanisms of odour object perception. Nat. Rev. Neurosci. 11, 628-641. doi: 10.1038/nrn2883

Haberly, L. B. (1983). Structure of the piriform cortex of the opossum. I. Description of neuron types with Golgi methods. J. Comp. Neurol. 213, 163-187. doi: 10.1002/cne.902130205

Harrison, N. L. (1990). On the presynaptic action of baclofen at inhibitory synapses between cultured rat hippocampal neurones. J. Physiol. 422, 433-446. doi: 10.1113/jphysiol.1990.sp017993

Isaacson, J. S., Solís, J. M., and Nicoll, R. A. (1993). Local and diffuse synaptic actions of GABA in the hippocampus. Neuron 10, 165-175. doi: 10.1016/08966273(93)90308-e

Jones, P. J., Xiang, Z., and Conn, P. J. (2008). Metabotropic glutamate receptors mGluR4 and mGluR8 regulate transmission in the lateral olfactory tractpiriform cortex synapse. Neuropharmacology 55, 440-446. doi: 10.1016/j. neuropharm.2008.06.043

Kapur, A., Pearce, R. A., Lytton, W. W., and Haberly, L. B. (1997). GABA Amediated IPSCs in piriform cortex have fast and slow components with different properties and locations on pyramidal cells. J. Neurophysiol. 78, 2531-2545. doi: 10.1152/jn.1997.78.5.2531

Kfir, A., Ohad-Giwnewer, N., Jammal, L., Saar, D., Golomb, D., and Barkai, E. (2014). Learning-induced modulation of the $\mathrm{GABA}_{\mathrm{B}}$-mediated inhibitory synaptic transmission: mechanisms and functional significance. J. Neurophysiol. 111, 2029-2038. doi: 10.1152/jn.00004.2014

Large, A. M., Vogler, N. W., Mielo, S., and Oswald, A. M. (2016). Balanced feedforward inhibition and dominant recurrent inhibition in olfactory cortex. Proc. Natl. Acad. Sci. U S A 113, 2276-2281. doi: 10.1073/pnas.1519295113

Ling, D. S. F., and Benardo, L. S. (1994). Properties of isolated GABA B-mediated inhibitory postsynaptic currents in hippocampal pyramidal cells. Neuroscience 63, 937-944. doi: 10.1016/0306-4522(94)90561-4

Neville, K. R., and Haberly, L. B. (2004). "Olfactory cortex," in The Synaptic Organization of the Brain, ed. G. M. Shepherd, 5th Edn. (New York, NY: Oxford University Press), 415-454.

Newberry, N. R., and Nicoll, R. A. (1985). Comparison of the action of baclofen with gamma-aminobutyric acid on rat hippocampal pyramidal cells in vitro. J. Physiol. 360, 161-185. doi: 10.1113/jphysiol.1985.sp015610

Oláh, S., Füle, M., Komlósi, G., Varga, C., Báldi, R., Barzó, P., et al. (2009). Regulation of cortical microcircuits by unitary GABA-mediated volume transmission. Nature 461, 1278-1281. doi: 10.1038/nature08503

Otis, T. S., De Koninck, Y., and Mody, I. (1993). Characterization of synaptically elicited $\mathrm{GABA}_{\mathrm{B}}$ responses using patch-clamp recordings in rat hippocampal slices. J. Physiol. 463, 391-407. doi: 10.1113/jphysiol.1993.sp019600

Poo, C., and Isaacson, J. S. (2011). A major role for intracortical circuits in the strength and tuning of odor-evoked excitation in olfactory cortex. Neuron 72, 41-48. doi: 10.1016/j.neuron.2011.08.015

Price, C. J., Scott, R., Rusakov, D. A., and Capogna, M. (2008). GABAB receptor modulation of feedforward inhibition through hippocampal neurogliaform cells. J. Neurosci. 28, 6974-6982. doi: 10.1523/JNEUROSCI.4673-07.2008

Riffell, J. A., Shlizerman, E., Sanders, E., Abrell, L., Medina, B., Hinterwirth, A. J., et al. (2014). Flower discrimination by pollinators in a dynamic chemical environment. Science 344, 1515-1518. doi: 10.1126/science.1251041

Scholz, K. P., and Miller, R. J. (1991). GABA B receptor-mediated inhibition of $\mathrm{Ca}^{2+}$ currents and synaptic transmission in cultured rat hippocampal neurones. J. Physiol. 444, 669-686. doi: 10.1113/jphysiol.1991.sp018900
Schuele, S. U., Kellinghaus, C., Shook, S. J., Boulis, N., Bethoux, F. A., and Loddenkemper, T. (2005). Incidence of seizures in patients with multiple sclerosis treated with intrathecal baclofen. Neurology 64, 1086-1087. doi: 10.1212/01.WNL.0000154639.35941.21

Schuler, V., Lüscher, C., Blanchet, C., Klix, N., Sansig, G., Klebs, K., et al. (2001). Epilepsy, hyperalgesia, impaired memory and loss of pre- and postsynaptic $\mathrm{GABA}_{\mathrm{B}}$ responses in mice lacking GABA $\mathrm{G}_{1}$. Neuron 31, 47-58. doi: 10.1016/s0896-6273(01)00345-2

Suzuki, N., and Bekkers, J. M. (2006). Neural coding by two classes of principal cells in the mouse piriform cortex. J. Neurosci. 26, 11938-11947. doi: 10.1523/JNEUROSCI.3473-06.2006

Suzuki, N., and Bekkers, J. M. (2010a). Distinctive classes of GABAergic interneurons provide layer-specific phasic inhibition in the anterior piriform cortex. Cereb. Cortex 20, 2971-2984. doi: 10.1093/cercor/bhq046

Suzuki, N., and Bekkers, J. M. (2010b). Inhibitory neurons in the anterior piriform cortex of the mouse: classification using molecular markers. J. Comp. Neurol. 518, 1670-1687. doi: 10.1002/cne. 22295

Suzuki, N., and Bekkers, J. M. (2011). Two layers of synaptic processing by principal neurons in piriform cortex. J. Neurosci. 31, 2156-2166. doi: 10.1523/JNEUROSCI.5430-10.2011

Suzuki, N., and Bekkers, J. M. (2012). Microcircuits mediating feedforward and feedback synaptic inhibition in the piriform cortex. J. Neurosci. 32, 919-931. doi: 10.1523/JNEUROSCI.4112-11.2012

Tamás, G., Lorincz, A., Simon, A., and Szabadics, J. (2003). Identified sources and targets of slow inhibition in the neocortex. Science 299, 1902-1905. doi: $10.1126 /$ science. 1082053

Tang, A. C., and Hasselmo, M. E. (1994). Selective suppression of intrinsic but not afferent fiber synaptic transmission by baclofen in the piriform (olfactory) cortex. Brain Res. 659, 75-81. doi: 10.1016/0006-8993(94) 90865-6

Tantirigama, M. L. S., Huang, H. H.-Y., and Bekkers, J. M. (2017). Spontaneous activity in the piriform cortex extends the dynamic range of cortical odor coding. Proc. Natl. Acad. Sci. U S A 114, 2407-2412. doi: 10.1073/pnas. 1620939114

Tseng, G.-F., and Haberly, L. B. (1988). Characterization of synaptically mediated fast and slow inhibitory processes in piriform cortex in an in vitro slice preparation. J. Neurophysiol. 59, 1352-1376. doi: 10.1152/jn.1988.59.5.1352

Vaughan, D. N., and Jackson, G. D. (2014). The piriform cortex and human focal epilepsy. Front. Neurol. 5:259. doi: 10.3389/fneur.2014.00259

Vismer, M. S., Forcelli, P. A., Skopin, M. D., Gale, K., and Koubeissi, M. Z. (2015). The piriform, perirhinal and entorhinal cortex in seizure generation. Front. Neural Circuits 9:27. doi: 10.3389/fncir.2015.00027

Wiegand, H. F., Beed, P., Bendels, M. H., Leibold, C., Schmitz, D., and Johenning, F. W. (2011). Complementary sensory and associative microcircuitry in primary olfactory cortex. J. Neurosci. 31, 12149-12158. doi: 10.1523/jneurosci.0285-11.2011

Wilson, D. A., and Sullivan, R. M. (2011). Cortical processing of odor objects. Neuron 72, 506-519. doi: 10.1016/j.neuron.2011.10.027

Conflict of Interest Statement: The authors declare that the research was conducted in the absence of any commercial or financial relationships that could be construed as a potential conflict of interest.

Copyright (C) 2018 Gerrard, Tantirigama and Bekkers. This is an open-access article distributed under the terms of the Creative Commons Attribution License (CC BY). The use, distribution or reproduction in other forums is permitted, provided the original author(s) and the copyright owner are credited and that the original publication in this journal is cited, in accordance with accepted academic practice. No use, distribution or reproduction is permitted which does not comply with these terms. 